\title{
The Research of the Approach to Integrating the Education of Innovation and Entrepreneurship with Professional Education
}

\author{
Zhao Haifeng \\ Zaozhuang University, Zaozhuang City, Shandong Province,China \\ Super_zhf@163.com
}

Keywords: Transformation,Innovation, Educational essence, Curriculum system.

\begin{abstract}
The curriculum system for the education of innovation and entrepreneurship in the universities is based on the national policies and theoretical framework for the disciplines, such as business administration. The actual survey and experience summary related to the current status of innovation and entrepreneurship among college students are still quite limited. It has led to the superficial education of innovation and entrepreneurship as well as the separation between professional education and the education of innovation and entrepreneurship, thus hindering the all-round development of college students seriously. Based on the actual condition of college students' employment as well as the summary of relevant problems and phenomena at the meso level, this paper is devoted to analyzing the cause and also proposing the optimization path and strategy.
\end{abstract}

\section{Introduction}

With the increasing national support for innovation and entrepreneurship and the implementation of various preferential policies, the call for mass entrepreneurship and innovation has been soaring. A variety of entrepreneurial competitions are being organized. It seems that the education of innovation and entrepreneurship has outperformed the professional education. It has become a controversial topic whether the intervention of the education of innovation and entrepreneurship will replace the professional education as the mainstream mode of education and employment for college students.

\section{Dominant position: The education of innovation and entrepreneurship or professional education}

The premier Li Keqiang has emphasized the mass entrepreneurship and innovation. Great support should be given to those college students who are an important force during the process of realizing their dream and value ${ }^{[1]}$. He also points out that China will have a bright future if most Chinese people can gain a sense of achievement from a challenging job and innovative career rather than merely take pleasure in consumption ${ }^{[2]}$. Therefore, innovation and entrepreneurship is not everything but just a means of employment for those college students. The overemphasis on the systematic and professional innovation and entrepreneurship will weaken the dominant position of professional education without doubt. Employment should not be confined to the modes such as self-employment and individual business. It should also include some challenging jobs which can offer opportunities for self-employment. The challenging jobs can offer college students more opportunities for innovation and entrepreneurship and a stronger sense of achievement. Hence, it is a more realistic and feasible means of innovation and entrepreneurship for college students. The ultimate aim of various concepts relevant to the education of innovation and entrepreneurship, such as the comprehensive and senior quality-oriented education combining innovative education and entrepreneurship education, is to cultivate the innovative entrepreneur and entrepreneurial innovator ${ }^{[3]}$. It is a type of teaching concept and mode aimed to satisfy the needs of the economic society and the strategy of national development ${ }^{[4]}$. It is more like an idealistic cultivation mode of innovation 
and entrepreneurship and can not provide theoretical support for the mainstream employment mode of college students.

Among various modes of employment available for college students, the traditional employment mode under the professional education has still occupied a dominant position. In this paper, the employment mode of those graduates in non-normal universities and colleges in Shandong in 2017 has been chosen as an example. The employment rate of self-employment and individual business, which are highly encouraged by the education of innovation and entrepreneurship, stands at 0.53 percent and 3.26 percent respectively. They have accounted for 3.79 percent of the total employment. The employment rate of labor contract, employment contract, further education, flexible employment and other employment modes under the mode of professional education stands at 37.64 percent, 22.2 percent, 10.32 percent and 16.79 percent respectively. They have accounted for 86.95 percent of the total employment ${ }^{[5]}$. It can be seen that there is still a long way to go before the education of innovation and entrepreneurship can replace the traditional employment views and modes which have occupied a dominant position. As shown by relevant survey reports, those graduates choosing a job related to their majors have accounted for 92.62 percent of all graduates. Therefore, how to improve the innovation and entrepreneurship based on the major and the current employment status will be a research topic with the realistic guidance significance.

It must be noted that the dominant position of professional education in the universities can not be challenged. Instead of overthrowing the existing employment views and modes, the education of innovation and entrepreneurship should absorb fresh blood, enhance its vitality as well as draw strength from the professional education. In this way, the education of innovation and entrepreneurship can find a proper position, identify the problems and find the solutions. The education of innovation and entrepreneurship will be also included in the objective of the talent cultivation system in the universities, thus improving the employment quality of college students.

\section{The approach and strategy for combining the education of innovation and entrepreneurship with professional education}

Considering that the professional education has occupied a dominant position and traditional employment is still a mainstream employment mode, it is worth researching the relationship between the education of innovation and entrepreneurship and professional education as well as how to realize the transformation and integration of the two modes of education, improve college students' awareness of innovation and entrepreneurship and increase their chance of succeeding in the innovation and entrepreneurship.

\subsection{Principles}

\subsubsection{The principle of respecting the dominant position of professional education}

Considering that most college students still tend to choose a job related to their major, the activities for the education of innovation and entrepreneurship should be carried out on the precondition of respecting the dominant position of professional education. The overly high frequency of the events and activities which are not related to professional education will disturb the professional teaching order seriously without doubt. Based on the professional education, the education of innovation and entrepreneurship can be integrated into the courses of general education, specialized basic courses and the courses for professional skills. The education of innovation and entrepreneurship will integrate with the professional education in many ways to cultivate the college students' spirit of innovation and entrepreneurship.

\subsubsection{The principle of combining theory with practice}

The education of innovation and entrepreneurship should not merely focus on cultivating the awareness of innovation and entrepreneurship. The practice and improvement of the skills of innovation and entrepreneurship is the key to stimulating the spirit of innovation and entrepreneurship. Practice is the core of the mode of teaching, learning and practice. In a sense, the teaching mode featured by university-enterprise cooperation is of greater help to the building of the curriculum system and the cultivation of the talent pursuing innovation and entrepreneurship. 
Firstly, the university can offer a number of excellent and well-educated teachers responsible for cultivating the college students' theoretical quality of innovation and entrepreneurship. Secondly, the enterprise can offer the platform for internship and practice so as to improve the practical skills of those college students.

\subsection{Optimize the teaching essence of the education of innovation and entrepreneurship}

\subsubsection{Objective}

At present, the teaching objective of innovation and entrepreneurship mainly focuses on cultivating the talents who pursue self-employment and individual business as well as encouraging college students to set up new companies with the policy support. However, how to find a good job related to their major and then pursue the innovation and entrepreneurship has been neglected and thus should be explored deeply. Besides encouraging self-employment, the teaching objective of innovation and entrepreneurship should also include awakening and stimulating the thinking of innovation and entrepreneurship for professional education, which is an important tasks at present and also represents the tendency of the education of innovation and entrepreneurship. It is a method of extending innovation and entrepreneurship to college students at a deep and broad level. It is also an effective method of enhancing the vitality of professional education and innovating in the teaching methods.

\subsubsection{Curriculum}

The integration of the theories of innovation and entrepreneurship and professional theories is the key to the innovative education. Therefore, based on the theories of entrepreneurship, it can extend to the professional theoretical knowledge at a deep level, which is the next key issue for the education of innovation and entrepreneurship. Some teaching materials for innovation and entrepreneurship have referred to the theoretical systems, such as business administration, financing and sociology. The design and establishment of professional education is still quite limited. The curriculum design is mainly concentrated in the building of the entrepreneurial team, entrepreneurial opportunity and risk identification, the design and development of business model, financing, resource management, entrepreneurial plan as well as the method and process of starting new enterprises. However, it is not widely applicable in the universities which offer various disciplines and require college students to focus on a certain research direction. The curriculum system is the basic approach to realizing the education of innovation and entrepreneurship and thus should be the first key issue to be addressed ${ }^{[6]}$. Therefore, the integration of professional education into the educational system of innovation and entrepreneurship should be realized.

\subsubsection{Subject}

The education of innovation and entrepreneurship has required that those students should have excellent application-oriented skills. At present, the education of innovation and entrepreneurship is mainly assumed by those teachers responsible for employment, the teachers of finance and the teachers of business administration. Although those teachers responsible for employment are familiar with the relevant policies and employment status, they lack the system of innovation and entrepreneurship and professional knowledge. Those teachers responsible for innovation and entrepreneurship have the excellent academic background of business administration and finance, but they can not well blend into the disciplinary systems of the university. Therefore, great efforts should be made to improve the cultivation of application-oriented skills and the training of innovation and entrepreneurship among those teachers. All teachers should be encouraged to participate in the education of innovation and entrepreneurship. In this way, the problem of the innovation and entrepreneurship teacher lacking professional knowledge and the innovation in professional education will be avoided. The building of double-position team is also the key to improving the effectiveness of the education of innovation and entrepreneurship.

\subsection{Establish the platform for innovation and entrepreneurship practice}

The aim of establishing a multi-channel platform for innovation and entrepreneurship is to encourage those college students to participate in various activities related to innovation and 
entrepreneurship. Those college students or projects with a bright prospect and great potential for innovation and entrepreneurship will be identified and selected. The relevant follow-up education and instruction will be also provided. In recent years, a variety of innovation and entrepreneurship competitions have been organized, such as career life planning and design competition, China College Students' Entrepreneurship Competition and Internet plus competition. Based on the professional education, those competitions have won a high recognition from the society with the great achievements of innovation and entrepreneurship. Compared with the professional competitions of innovation and entrepreneurship, the disciplinary competition has a higher degree of participation and can provide excellent talents and projects for the competition of innovation and entrepreneurship. The further integration, transformation and large-scale expansion of disciplinary competition and the education of innovation and entrepreneurship is of great significance to the education of innovation and entrepreneurship.

A close partnership with the studios and student associations will be established. The studios and student associations are carried out under the instruction of professional teachers. The two active organizations are engaged in innovative activities. Therefore, the education of innovation and entrepreneurship can cooperate with the studios and student associations to organize various competitions for innovation and entrepreneurship. When communicating with each other, college students will also acquire the thinking and ability for innovation and entrepreneurship.

\subsection{Enhance the organizational guarantee and system building}

The establishment of the organization and the improvement of the system can provide strong support for the unified organization and coordination of the education of innovation and entrepreneurship. The education of innovation and entrepreneurship requires the mutual coordination and communication between career guidance center, teaching faculty, student union and Youth League committee. They should regularly discuss how to solve various tricky problems existing in the operation process of innovation and entrepreneurship. Hence, it can play an important role in facilitating the establishment of the curriculum system for the education of innovation and entrepreneurship. In addition, the improvement of the system can provide the basic guarantee for innovation and entrepreneurship. Based on their actual condition, those universities should also adjust the reward and punishment mechanism for the education of innovation and entrepreneurship. The relevant reward and credit should be given to those college students and instructors winning a prize in various competitions of innovation and entrepreneurship. The honor of innovation and entrepreneurship should be also considered for evaluating the excellent teachers or students. Moreover, the special fund for innovation and entrepreneurship should be set up to support the excellent projects of innovation and entrepreneurship and give those college students a better chance of succeeding in the innovation and entrepreneurship.

Conclusion

\section{Summary}

With the accelerating globalization and transformation of the Chinese economy, there is a growing demand for innovative talents. Higher education is expected to accelerate the educational reform, combine the education of innovation and entrepreneurship with professional education as well as improve the talent cultivation objective and curriculum system so that those college students will acquire the spirit of innovation and entrepreneurship and better adapt to the social development.

\section{Reference}

[1] New Engine Releases New Power: Mass Entrepreneurship and Innovation, Xinhua Net, http://www.xinhuanet.com/fortune/2015-03/06/c_127550234.htm

[2] New Engine Releases New Power: Mass Entrepreneurship and Innovation, Xinhua Net,http://www.xinhuanet.com/fortune/2015-03/06/c_127550234.htm 
[3] Peng Diyun,The Foundation of Innovation and Entrepreneurship for College Students , Nanchang: Jiangxi University Press,pp.286,vol,06,2016

[4] Ministry of Education: The Opinions on Pushing Forward the Education of Innovation and Entrepreneurship in the Universities and the Self-employment of College Students, Ministry of Education ,pp.3,2010

[5] Data Source: The Report on the Employment Quality of College Graduates in Shandong in 2017, http://www.sdbys.cn/art/2018/1/15/art_21_78734.html

[6] Zhao Huili, The Establishment of the Curriculum System for the Education of Innovation and Entrepreneurship in the Universities under the Background of Mass Entrepreneurship and Innovation ,China Adult Education, P101, vol. 22, 2016 